\title{
MEKASID (CILJEVI I INTENCIJE) U HANEFIJSKOME MEZHEBU
}

\section{SAŽETAK}

Svi pravni sistemi, stari $i$ novi, nebeski i konvencionalni, $u$ teoriji se temelje na priskrbljivanju koristi i izbjegavanju štete, uz razlike poimanja štete ili koristi, odnosno metode izbjegavanja štete ili priskrbljivanja koristi... Nebeski sistemi određuju te kategorije, a logika i razum ih potvrđuju, za razliku od konvencionalnih, ljudskih, koji to prepuštaju samo razumu.

U savremenom dobu osjeća se nužna potreba za izučavanjem $i$ primjenom ciljeva $i$ intencija u Šerijatu kako bi se vjera prenijela iz teorije u praksu, u svim vidovima ljudske aktivnosti ${ }^{2}$

Zanimanje za ciljeve $i$ intencije Šerijata pojavilo se iz dva posebna razloga:

1. širenja islamskog svijeta,

2. neraskidive veze između ideje ciljeva $i$ intencija (u Šerijatu) $i$ savremenih reformističkih tendencija.

$U$ hanefijskom mezhebu, i u njegovim fundamentima, ne postoji razradena teorija ciljeva i intencija (mekasid) kao samostalnih, zasebnih pravnih pitanja $i$ rješenja, nego se baš zbog prirode ove pravne škole $i$ specifičnosti njene metodologije islamske jurisprudencije, u praktičnim pravnim propisima (الفروع الفقهية), praktično sprovodi teorija mekasida.. Metodolozi islamske jurisprudencije hanefijskog mezheba, dakle, nisu sistematizirali teoriju intencija i ciljeva u mezhebu ali ova škola kroz:

\footnotetext{
${ }^{1}$ Islamski pedagoški fakultet u Bihaću

2 Vidi knjigu: مقاصد الثريعة وقضايا العصر (Ciljevi, intencije u Šerijatu i savremena pitanja) objavljenu u izdanju, Centra za izučavanje ciljeva i intencija Šerijata, koja se specijalno bavi izučavanjem i primjenom ove nauke. Radovi iz spomenute knjige su savremena gledišta u metodologiji islamske jurisprudencije, ekonomiji, politici, sociologiji, pravu i pravnim teorijama, s novim osavremenjenim reformističkim stajalištima koja su otvorila put ka ciljevima i intencijama u različitim domenima.
} 
-princip istihsana,

-sistematizaciju pravnih pravila, $i$

-poglavlja, tzv., hijel (pravne lukavštine) ili meharidž (originalno i inteligentno) primjenjuje metodu ciljeva i intencija.

Ovim se radom, upravo, bavimo mekasidom (ciljevima $i$ intencijama) $i$, tzv., hijelom u hanefijskome mezhebu.

\section{Ključne riječi:}

Ciljevi - intencije, hanefijska pravna škola ili mezheb, islamsko šrijatsko pravo, jurisprudencije, mekasid, metodologija islama, pravne doskočice ili lukavštine, Šerijat.

\section{Uvod}

Metodologija islamske jurisprudencije je u uskoj vezi sa intencijama i ciljevima Šerijata postavljenim u samim njegovim temeljima, koji upućuju na praktične propise u normama Uzvišenoga, a koje se odnose na djela adresanata i subjekata prava.

Dakle, ciljevi $i$ intencije su prisutni u samom svetom tekstu od početka islama, a mudžtehid ih otkriva idžtihadom, proučavanjem i pravničkim rasuđivanjem, te udubljivanjem $u$ intencije $\mathrm{i}$ ciljeve norme. Imamul-Haramejn el-Džuvejni u tom smislu smatra, da ne izmišlja niti inovira, nego samo primjećuje šerijatski sud, pomažući se onim što vidi i prouči.

Trag intencija i ciljeva se pokazuje na propisima pravnih situacija podložnih promjenama - promjenama vremena i mjesta. Da ne postoji svrha postizanja određenih ciljeva $\mathrm{i}$ intencija, ne bi se mijenjao ni propis samo shodno promjeni vremena i mjesta.

Šerijat je kauzalno vezao efektivni uzrok s ciljevima i intencijama, tako da postoji njihova korelacijska veza.

Konačno, čemu služe tahridžul-menat (تخريج المناط) i tenkihulmenat (تفقيح المناط) u metodologiji islamske jurisprudencije, osim kako bi se otkrile intencije i ciljevi Šerijata u tom propisu. Dakle, mekasid su kategorije koje definitivno postoje u metodologiji učenjaka, iz razloga da bi se ostvarila korist adresantima i subjektima prava $u$ vremenskom totalitetu ovoga i onoga svijeta. 


\section{Ciljevi i intencije u mezhebima}

Imam Malik opširno raspravlja o značenju ciljeva - intencija javnoj koristi (المصالح المرسئة) i preventivnom sankcioniranju (سد الأرائع).

Imam Ahmed je izrazio veliko zanimanje za mekasid u svome Musnedu.

Što se tiče neehlisunnetskih mezheba, kao što su šije imamije, oni su prevashodno bili zainteresirani za područje ciljeva i intencija.

Metoda izvođenja pravnih propisa ili pozitivizacija prava (منهج الاستتباط), jeste krajnji domet metodologije islamske jurisprudencije, gdje se prema islamskome fikhu odnosi kao prema zajednici mezheba. Kada je riječ o mezhebu kodifikovanog prava on gleda na fikh kao na upotpunjenu cjelinu potirući mezhepsku različitost.

I u samoj metodi primjene (منهج التطبيق) dolazi do upotrebe pravne logike u ostvarivanju ciljeva i intencija šerijatskih propisa, dozvoljavanjem postupnosti u uzimanju i primjeni propisa.

Ako izuzmemo neku ulemu iz zahirijskog mezheba, čitav islamski ummet je na stajalištu, da su Šerijat i njegovi propisi sama mudrost, milost $\mathrm{i}$ korist čovječanstvu u vremenskom totalitetu, uspjeli ili ne uspjeli to razumjeti i otkriti.

Uzvišeni kaže:

\section{وما أرسلناك إلا رحمة للعالمين}

A Tebe smo samo kao milost svjetovima poslali. (ElEnbija:107)

Kurtubi, u komentaru ovog ajeta, kaže: Nema razlaza među onima koji imaju pameti da su zakoni poslanika i vjerovjesnika imali intenciju priskrbljivanja koristi ljudima u vremenskom totalitetu, ovosvjetski $i$ onosvjetski, a imam Šatibi kaže: Zakonodavac je, po konsenzusu, postavio Šerijat na osnovama koristi.

Sa ovog osnova Ibnul-Kajjim tvrdi: Građevina Šerijata i njeni temelji su učvršćeni na mudrosti $i$ koristi koju priskrbljuje čovječanstvu u življenju na ovom i budućem svijetu. Šerijat je sama pravda, sama milost i sama korist. Svako pitanje koje izađe izvan 
pravde u domen nepravde ili iz okrilja milosti u njenu suprotnost, ili iz koristi u štetu, iz mudrosti u igrariju, nije šerijatsko, makar u njega ušlo te'vilom i personalnim tumačenjem. ${ }^{3}$

Ashabi su bili prvi koji su zagovarali i usuglasili se da je Šerijat korist, a njegovi propisi u okvirima dobra koje se priskrbljuje ili štete koja se otklanja, tako da su, prirodno, prvi zagovornici i prvi čuvari šerijatskih intencija i Allahovih mudrosti. Ibnul-Kajjim kaže: Ashabi su bili generacija koja je najbolje razumijevala $i$ najispravnije slijedila Allahovog Poslanika, a. s. Raspravljali su samo o pokušajima razumijevanja i shvatanja njegovih ciljeva i intencija. ${ }^{4}$

Ebu-Ishak eš-Šatibi, koji slovi učiteljem i autoritetom za pitanje teorije ciljeva $\mathrm{i}$ intencija, iskazao je bojazan da će njegove reformističke ideje, u vrijeme dekadence, naići na nerazumijevanje i čuđenje. Opravdanje je našao u činjenici da to potvrđuju ajeti i vijesti od Allahovog Poslanika, a. s., i u praksi pravovjernih prethodnika, kao i u tome da su vrsni učenjaci dali za njih smjernice i temelje kroz teoriju - tako da je put mekasida, jasno omeđen i ne može se zanijekati. Zbog toga on posebno spominje ashabe kao generaciju, koja je poznavala intencije Šerijata, dosezala njegove ciljeve u primjeni, utemeljila i učvrstila njegove fundamente, ukazala na značenja ajeta - zorno radeći na otkrivanju njihovih temeljnih značenja. $^{5}$

Kada ovo znamo, onda je jasno da intencije Šerijata i njegove ciljeve nisu otkrili savremeni učenjaci, nego je to sama osnova vjere, od prvoga dana i od prvoga razumijevanja. Prva dva izvora Šerijata, Kur'an i sunnet, su prvi ukazali na intencije i ciljeve Šerijata, i prvi koji su upozorili na njih, dajući generalne i parcijalne primjere, te njihove metode otkrivanja i prakticiranja. Usprkos činjenici da nebeske norme imaju svoju svetost (definitivne su i neupitne kod vjernika koji im se bespogovorno podčinjavaju) uprkos tome što nemaju potrebu ni za ukazivanjem na efektivni uzrok, mudrost, cilj, intenciju ili korist, ipak pojašnjavaju u dijelu obredoslovlja i u

\footnotetext{
3 Ibnul-Kajjim El-Dževzijje, I'alamul-muvekki'in an rabbil-alemin, Darul-kutubili'lmijje, 1991, Bejrut, 3/3.

${ }^{4}$ Ibid.

5 Ebu-Ishak Ibrahim b. Musa eš-Šatibi, El-Muvafekatu fi usuliš-šeri'ah (Sklad u temeljima islamskog prava), Darul-ma'rife, bez godine izdanja 1/25.
} 
praktičnim pravnim propisima građanskoga i drugih grana prava, mnoge efektivne uzroke propisima, njihove ciljeve $\mathrm{i}$ intencije. Tu se radi o više od hiljadu primjera čiji se ciljevi i intencije manifestiraju kroz različite načine. ${ }^{6}$

\section{Terminologija intencija}

Ulema u ovu tematiku ubraja različitu terminologiju čija značenja se temelje na intencijama i ciljevima i onome što spada pod te pojmove, kao što su izrazi:

1. efektivni uzrok, (العلة والعلل)

2. mudrost i korist, (الحكمة والمصلحة)

3. značenje $i$ smisao, pouka, domašaj, domet, moto, naravoučenije, (المغنى والمغزى)

4. cilj šerijata, (مراد الشرع)

5. tajne šerijata. (أسرار الثريعة)

Zbog te raznovrsnosti ulema se razišla u definiranju šerijatskih ciljeva i intencija (المقاصدالثرعية) tako da ih vide kao ciljeve Zakonodavca (غرض الثارع), ili ono što On htjede (ما أراد الشارع), ili ono

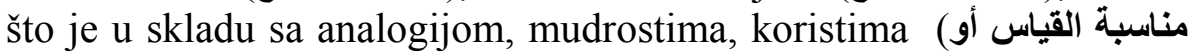
(الحكمة - والمصلحة), ili javnim koristima (المصالح المرسلة).

Ciljni put (النسق المقاصدي) pozitivizacije prava ili pravničkog rasuđivanja, bio bi čuvanje i zaštita pet nužnih vrijednosti (الضروريات zatim udovoljavanje potreba (الحمس (الخيات) i na koncu postizanje luksuza. (التحسينات)

\section{Ciljevi i intencije kod savremenih autora}

Savremeni autori dijele mekasid (ciljeve i intencije) na:

1. Opće (عامة) - postoje u svim vrstama pravnih sistema kao što su: olakšice (التيسير), dobrostivost ( السماحة), pravda (العزيل), العدل), sloboda (الحرية);

${ }^{6}$ Ibnul-Kajjim el-Dževzijje, I'alamul-muvekki'in an rabbil-alemin, Darul-kutubili'lmijje, 1991, Bejrut, 1/169-200. 
2. Posebne (خاصة) - postoje u nekim poglavljima, kao što je zakidanje i šteta u prodaji (الغرر في البيوع), pretjerano kažnjavanje kod sankcija (الردع في العقوبة) i sl;

3. Parcijalne (djelomične) (جزئية) - obuhvataju propis, tajne i ciljeve koje nastoji ostvariti Zakonodavac kao što su: istina (الصدقل)), vjerodostojnost svjedoka (ضبط الشهود), otklanjanje teškoća ( رفع المشقة) (والحرج i sl.

Idžtihad, u domenu metodologije intencija i ciljeva, daje svrsishodno razumijevanje norme. Tako je poimanje slobode, kod starih autora, bilo izlazak iz ropstva, dok se njeno savremeno poimanje krucijalno razlikuje od toga značenja. Isti je slučaj sa razlikama u poimanju čuvanja i zaštite pet nužnih vrijednosti. Ima ih koji smatraju da se sankcionira:

1. Javnošću - kako bi se čuvao i štitio princip sakrivanja i neoglašavanja;

2. Pljenidbom - kako bi se čuvao i štitio imetak;

3. Smrtnom kaznom - kako bi se čuvao i štitio život;

4. Gubitkom suvereniteta - kako bi se čuvala i štitila vjera.

Sva su savremena intencijska pravnička razmišljanja potrebna novim proučavanjima, kako bi se uskladila sa šerijatskim tekstovima, i vezala za slične pravne situacije nastale u muslimanskim društvima koje bi bile rješavane na odgovarajući način, analogno vremenu i njegovom društvenom napretku.

Isto se tako stimuliše na idžtihad, u domenu teorije intencija i ciljeva metodologije islamske jurisprudencije.

Ibn-Ašur je kritikovao nauku metodologije islamske jurisprudencije radi zanimanja za pozitivizaciju pravnih propisa, bez udubljivanja $u$ intencije i ciljeve, što su kao metodu odobrili EbuZehre, Abdullah Draz, Hasan et-Turabi i dr., zagovarajući program, u kojem će generalne intencije i ciljevi nadvladavati parcijalne pojedinačne fikhske propise.

Upućivanje na propis može biti eksplicitno ali i implicitno, što potvrđuju neki tradicionalni tekstovi u pogledu kojih od početka postoji razlaz u tumačenju (hadisi): 


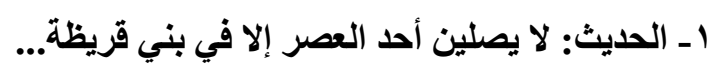

1. Neka niko od vas ne klanja ikindiju, nego u prebivalištu plemena Benu-Kurejza ...;

(ovdje su se ashabi razišli u tumačenju)

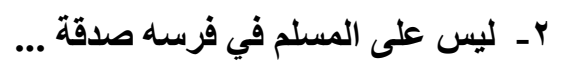

2. Musliman ne mora da daje zekjat na konja ...;

(a Omer je uzeo zekjat na konje)

$$
\text { r- من قتل قتيلا فله سلبه. }
$$

3. Ko ubije nekoga u borbi, pripada mu njegovo oružje ...;

$$
\text { ع- المؤلفة قلوبهم ... }
$$

4. Distribucija zekjata onima koje treba pridobiti u islam. (المؤلفة قلوبهر);

(Omer je dokinuo i nije dao Ajini i El-Akreu')

$$
\text { هـ وأن في النفس الدية مائة من الإبل ... }
$$

5. Krvarina za ubistvo osobe je stotinu deva.

(Omer je to uzeo kao novčanu protuvrijednost za stanovnike Šama i Egipta)

Svi ovi tekstovi su protumačeni zanemarujući osnovno značenje. $\mathrm{Ni}$ iz kojega drugoga razloga, nego što su se uzele u obzir šerijatske intencije i ciljevi.

Prema tome, uzimanje po ciljevima i intencijama koje treba da se ostvare nekim propisom, jeste jedan srednji put između čistih bukvalista, koji uzimaju striktno po slovu zakona, i logičara koji uzimaju samo na temelju razuma.

\section{Rješavanje kontradikcije u tekstu metodom ciljeva i intencija}

U osnovi kontradikcija i ne postoji. Javlja se u ograničenom broju hadisa zbog nedostatka prenosioca, što se rijetko događa, a ulema je inovirala metodu kako se u tom slučaju rješava kontradikcije: usaglašavanjem (الجمع), derogacijom (النسخ), preferiranjem (النّا) (الترجيح), neodlučivanjem (التوقن), odbacivanjem (التساقط)), te odabirom (التخيير). 
Rješavanja kontradikcije metodom upotrebe ciljeva i intencija ima dokaze u:

1. Razumijevanju i tumačenju postupaka Allahovog Poslanika, a. s., kroz nužne intencije i ciljeve, kao što su zabrana ostavljanja i štednje kurbanskoga mesa preko tri dana, a onda dozvoljavanje toga, radi nužde. Isto tako, zabrana posjete mezarima ženi a potom dozvola, radi mogućnosti da se nastavi sa džahilijetskim običajem i praksom;

2. Uzimanju u obzir intencije olakšica raznovrsnošću, postupnošću i običajem:

3. Raznovrsnošću, u smislu da Šerijat, na takav način, daje olakšice za svako vrijeme i mjesto;

4. Postupnošću, radi teškoće prelaska čovjeka, odjednom, na drugi metod življenja; (postupnost u zabrani alkohola, kamate, obaveze namaza, itd);

5. Običajem, jer se zna da je Allahov Poslanik, a. s., potvrdio neke govorne i praktične običaje koji se ne protive Šerijatu.

U skladu s balansom koristi i pozitivizacijom savremenih pravnih događaja, priskrbljivanjem koristi a izbjegavanjem šteta, poznavanjem preferiranih vrijednosti $\mathrm{u}$ određenom vremenu, vaganjem i balansiranjem, te teorijom realiteta, svaka stvar koja vodi šteti zabranjena je, a svaka stvar koja vodi koristi, dozvoljena je.

Sredstva uzimaju propis intencije i cilja tako, da svako sredstvo koje vodi ka šteti je zabranjeno, a ono koje vodi ka koristi je dozvoljeno je i sl.

Ljudska prava (حقوق الإنسان) su zastupljena kroz ostvarivanje ciljeva i intencija Šerijata, čiji preferirani cilj jeste čuvanje i zaštita čovjeka i njegovoga života (حفظ النف) u svakoj situaciji, svakom vremenu i prostoru - na šta, kao Allahovo stvorenje, čovjek ima pravo.

U savremenim razmišljanjima, sa stajališta intencija i ciljeva, dolazi opravdana kritika globalizacije (العولمة):

1. Islam štiti vjeru - globalizacija je druga vjera;

2. Islam ima određene standarde - globalizacija ima dvostruke standarde; 
3. Islam štiti čovjeka - globalizacija trguje s ljudima;

4. Islam štiti pamet - globalizacija se razilazi s pameću kad god hoće;

5. Islam čuva imetak $\mathrm{i}$ radi na približavanju bogatog $\mathrm{i}$ siromašnog - globalizacija pravi razdor među njima i na državnom i na privatnom planu;

6. Islam, dakle, učestvuje u davanju primjera informacijskog sistema koji će voditi svijet - a globalizacija porađa program koji svijet ne vodi dobru.

\section{Razvoj teorije i ideje intencija}

Nalazimo tri imena u ovoj tematici, koja su dala veliki doprinos i bili imami, i originalni predvodnici u ovoj nauci a to su:

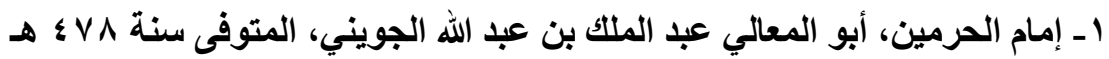

1. Imamul-Haremejn, Ebul-Me'ali Abdul-Melik b. Abdullah elDžuvejni (umro 478. H.)

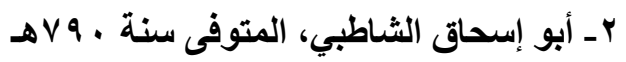

2. Ebu Ishak eš-Šatibi (umro 790. H.)

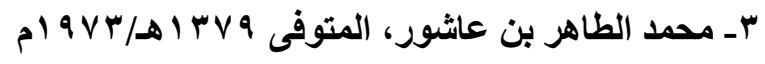

3. Muhammed et-Tahir b. Ašur (umro 1379. H.)

Ideju i teoriju ciljeva i intencija nalazimo u radovima ove trojice velikana, uz doprinos onih prije i poslije njih - od kojih su uzeli, i one - na koje su ostavili utisak, tako da kod njih nalazimo najvažnije stanice u razvoju ove misli, te njima sličnima.

Uzvišeni Allah je apsolutno neovisan, nije u potrebi ni za čim, niti je u Njegovom slučaju moguća šteta ili korist, tako da On ne dozvoljava niti zabranjuje Sebe radi i radi lične koristi ili sprečavanja štete Sebi, nego iz razloga priskrbljivanja koristi i dobra za svoje robove.

I u slanju poslanika je mudrost i opća društvena korist $\mathrm{u}$ uspostavljanju principa naredbe dobra, i zabrane lošega i zla. 
El-Hakim et-Tirmizi prvi je, koji je termin mekasid upotrijebio, u samom naslovu svoje knjige. (الصلاة ومقاصدها)

Ebul-Hasen al-Amiri (umro 381. H.) prvi je spomenuo pet univerzalnih vrijednosti u islamu, koje su kroz vjekove, ostale centar oko kojeg se vrti priča o ciljevima i intencijama Šerijata.

Doprinos je i mu'tezila, koji su u razmišljanjima o Božijoj pravdi, Božijoj dobroti, o kvalifikaciji dobra i najboljeg, dobroga i ružnoga u osnovi, dali teoriju ciljeva i intencija. Istu takvu ulogu odigrala su i logička, racionalna objašnjenja i obrazloženja od Fahrurazija o efektivnim uzrocima propisa u Šerijatu i njegovim koristima. Mu'tezilije su racionalnim apstrahiranjem zaključili, da je ružno i negativno nespojivo sa Njegovom Uzvišenom Osobom. Radi toga je onda nužno, da mu je aktivnost građena na principima koristi i cilja.

Pionirski je doprinos Imamul-Haremejna ideji ciljeva i intencija. $^{7}$ Od njega i njegovoga učenika Gazalija upotrebljava se specifična terminologija, kao osnova u bilo kakvom govoru o ciljevima i intencijama Šerijata. Šerijat sadrži naredbe (مأمور به), zabrane (ومنهي عنه) i dozvoljeno (مباح....). Vjera se štiti i čuva ibadetom, život kaznom taliona, porod i obraz se čuva i štiti kaznom za zinaluk i potvoru, te se imetak štiti kaznom odsijecanja ruke itd.

U epohi, između Imamul-Haramejna i Šatibija, imamo EbuHamida el-Gazalija, Ibn-Rušda, Ibnul-Arebija, Fahruddina er-Razija,

\footnotetext{
${ }^{7}$ Šerijatski ciljevi i intencije se dijele na: nuždu, potrebu i luksuz. Da bi se moglo razlikovati korisno, ono što treba preferirati ili odgoditi, ono gdje treba olakšati ili gdje nema kompromisa, ono što se može tolerisati ili ne i sl. Dakle, dijele se na:

1. Ono što je vezano za nuždu, kao što je kazna taliona. Njegovo je opravdanje zaštita prolijevanja nevine krvi i kazna za one koji je proliju;

2. Ono što je vezano za opću potrebu i ne penje se na stepen nužde. Primjer za to je ugovor o zakupu između ljudi;

3. Ono što nije nužno ni na stepenu opće potrebe, nego je na stepenu mekreme;

4. Ono što nije nužno niti na stepenu opće potrebe, niti je na stepenu treće kategorije i ograničava se na mendub;

5. Ono što ne primjećuje jasno opravdanje niti ograničen cilj, tako da nije niti na stepenu nužde, niti na stepenu potrebe, a ni na stepenu mekreme - to je jako rijetko u praksi.

Pet nužnih univerzalnih vrijednosti (الضروريات الخمس) su:

vjera, život, porod, pamet i imetak. (الدين، والنفس، والنسل، والعقل، والمال) 
Amidija, Izzuddin b. Abdus-Selama, El-Karrafija, Et-Tufija, IbnTejmiju, Ibnul-Kajjima el-Dževzije itd.

U hanefijskom mezhebu imamo Ebu-Abdullaha Muhammeda b. Abdur-Rahmana el-Buharija koji je umro 546. H. a napisao je knjigu (محاسن الاسلام وشرائع الاسلام).

Šatibi se, po konsenzusu, smatra osnivačem ove nauke. Sakupio je ono što je urađeno prije njega, ali na naučan način sa dodacima i ocjenama, upotpunjavajući tako čitavu teoriju ove nauke.

Zbog stagnacije islamskog ummeta i dekadence koja je nastupila, Šatibi je ostao neiskorišten sve do prošloga stoljeća - do Ibni-Ašura.

Ibnu-Ašur je drugi učitelj, odmah za Šatibijem, ili prvi koji je jasno pozvao na utemeljenje nove nauke ilmul-mekasid.

Mekasidul-Kur'an nije ograničena na ajete ahkjama. Svi ajeti i hadisi imaju svoje ciljeve i intencije (mekasid). Zato je obaveza da se prouče i razumiju. Čak i kur'anska kazivanja (pripovjesti) imaju mekasid, kao i dove te primjeri (emsal) iz sunneta i Kur'ana. Glavni, ali ne i jedini cilj dove je jasan. To je želja, da se udovolji njenom sadržaju od Uzvišenog Allaha.

Međutim, dova sadrži i neke ciljeve i intencije akaidske, obrazovne, odgojne i zakonodavne prirode.

\section{Metoda intencija i ciljeva u hanefijskom mezhebu}

Metodologija hanefijske pravne škole pojmovno-logičku obradu prava (fikha) i njegovu tehniku stvaranja, izvodi putem utvrđivanja i postavljanja općih pravnih načela i pravnih institucija indukovanih iz parcijalnih praktičnih rješenja, koja je dao utemeljivač mezheba EbuHanife sa svojim učenicima. Ovaj se metod odlikuje praktičnošću. To je, dakle, praktično analitičko studiranje pojedinačnih pravnih normi ili pravnih propisa i rješenja, iz čijega se kazuističkog načina rješavanja (od slučaja do slučaja) dolazi procesom logičkog apstrahovanja do općih zakonitosti, koje se sintetiziraju u opća pravna načela i pravne institucije. Ova metoda, služi pozitivizaciji prava, i opravdava metodologiju mezhepskih utemeljivača koju su upotrijebili kod normiranja pojedinačnih normi ili propisa. 
Ibn-Haldun smatra da je ova metodologija najpriličnija i najpraktičnija za fikhsko normiranje.

U skladu s ovom praksom, kod utemeljivača hanefijskog mezheba i u njegovim fundamentima, ne postoji teorija ciljeva $i$ intencija (mekasid) kao kod spomenute uleme, ali se mogu primijetiti u praktičnopravnim propisima (الفروع الفقهية), što je prirodno za hanefijsku metodologiju islamske jurisprudencije. Metodolozi islamske jurisprudencije, hanefijskog mezheba, dakle, nisu sistematizirali teoriju intencija i ciljeva u mezhebu ali ova škola kroz princip istihsana, sistematizaciju pravnih pravila, te poglavlja tzv. hijel ili meharidž - primjenjuje metodu ciljeva i intencija na vrlo originalan način.

\section{Ostvarivanje intencija hilama (pravne doskočice - lukavštine)}

Hijel ili pravne doskočice - lukavštine, jesu posebno poglavlje u hanefijskoj pravnoj školi. Hile ( $p l$. hijel) se, u šerijatskoj pravnoj enciklopediji, definira kao nešto dozvoljeno i propisano - čime se čini prekršaj, ili kao ono što liči na dozvoljeno a nije dozvoljeno. ${ }^{8}$

Hanefijski pravnici su se razišli o pitanju naziva ovoga Poglavlja. Neki su ga nazvali Kitabul-hijel, tj. Poglavlje pravnih lukavština, fikcija, trikova, a drugi su uzeli naziv Kitabul-meharidž, tj. Poglavlje pravnih izlaza, izbavljenja i rješenja. Za Muhammeda kažu da je to Poglavlje nazvao Kitabul-hijel. Međutim, Ebu-Sulejman je kategoričan:

Slagali su na Muhammeda. On nema u svom fikhu Kitabul-hijel nego poglavlje El-Herebu minel-haram (Bježanje od harama), odnosno Izbavljenje od harama - a to je pohvalno. Uzvišeni Allah kaže: 'I uzmi rukom svojom snop i njime udari, samo zakletvu ne prekrši!! (Sad: 44) Naravno, ova rješenja, u vidu pravnih lukavština, pravovaljana jesu ako se njima nikome ne čini šteta ${ }^{9}$

\footnotetext{
8 dr. Muhammed Revas Kal'atdži, dr. Hamid Sadik Kanibi, Mu'džemu lugatilfukahai, a'rebi-inklizi, Arapsko-engleska enciklopedija šerijatsko-pravne terminologije, Darun-nefais, 1985, Korijen: hile, 189.

${ }^{9}$ Vidi: Ibnu-Nudžejm, El-Ešbahu ven-nezairu a la mezhebi Ebi Hanifeten-Nu'man (Sličnosti $i$ uporednosti pravne škole Ebu-Hanife en-Nu'mana), Darul-kutubili'lmijje, Bejrut, 1993., 405.
} 
Dakle, u pravno-terminološkom značenju, hijel su pravne lukavštine, doskočice ili pravna rješenja koja omogućuju izlaz iz neke teške pravne situacije, kao što je kod hanefijskih pravnika, koji prihvataju originalno mišljenje pravnika Muhammeda u primjeru otklanjanja štete siromahu, na način da zajmodavac putem pravnoga trika naplati svoje dugovanje, a ujedno da pomogne i dotičnog siromaha. Naime, ako je vjerovnik obavezan davati zekjat, može ga dati svom dužniku siromahu, a onda od njega zahtijevati vraćanje duga. U slučaju da mu ovaj, opet, ne htjedne vratiti dug ni na takav način, onda ima pravo da pruži ruku i uzme svoje pravo, ili da ga prijavi kadiji koji će mu narediti izvršenje obaveze vraćanja duga. Isto tako, kod onoga ko ima vrijednost nisaba (količina koja podliježe obavezi zekjata), pa hoće da izbjegne tu obavezu, dijeleći količinu koja će okrnjiti nisab, prije nego što se upotpuni obavezujući period posjedovanja nisaba. ${ }^{10}$ Hanefijski pravnici se razilaze oko pitanja pokuđenosti ovoga rješenja.

Za klanjača koji klanja podne-namaz, u toku čega zauči ikamet za zajedničko klanjanje, vrjednije po tekstu hadisa za dvadeset pet, odnosno, po drugoj verziji dvadeset i sedam puta, hile bi bilo da produži sa klanjanjem poslije četvrtog rekjata, kako bi mu se taj namaz tretirao nafilom (dobrovoljni namaz), a ne obaveznim podnenamazom. Potom bi klanjao podne, zajedno sa džematom, ostvarujući uvećanu vrijednost zajedničkog načina obavljanja namaza.

U slučaju postača, koji izvršava kaznu kefareta postom dva uzastopna mjeseca prije ramazana (redžeb i ša'ban) ${ }^{11}$, nakon čega se ispostavi da je pogriješio kod određivanja početka hidžretskih mjeseci,

${ }^{10}$ Malik i Ahmed smatraju, da ovakvo izbjegavanje zekjata nije dozvoljeno i propisuju obavezu zekjata, makar se ne upotpunio havl (obavezni period od godinu dana koji mora proći nakon što se upotpunio nisab imetka, kako bi zekat bio obavezan). Međutim, ako se smanjivanje nisaba (obavezna količina imetka na koju se daje zekjat) desi na početku perioda havla, onda se to može prihvatiti i ne tretira se trikom za izbjegavanje zekjata. Ebu-Hanife i Šafija smatraju, da u slučaju smanjivanja imetka prodajom jednog dijela, poklanjanjem ili uništavanjem, tako da njegova količina bude ispod nivoa nisaba čak i neposredno pred kraj havla uzrokuje prestanak obaveze zekjata. Međutim, onaj ko to uradi, u pokušaju da izbjegne zekjat, spada u red grješnika koji se ogriješio prema Bogu. Sejjid Sabik, Fikhus-sunne (Islamsko pravo u sunnetu), Darul-fikr, Bejrut, 1977, 1/323.

11 Jedna je od izbornih kazni kefareta neprekidni post svakoga dana, kroz dva uzastopna mjeseca. 
što je imalo za posljedicu da je došao ramazan i nova obaveza posta a nije upotpunio dva mjeseca i obavezu kefareta. Mukellef ili pravni subjekt se ovdje našao u situaciji da ne može postiti zadnji dan kefareta zbog ramazanske obaveze posta koja je jače pravne snage, tako da mu propada post kefareta koji je gotovo završio. Naime, pravno mu propada post kefareta ako ne bi upotpunio dva mjeseca uzastopnoga posta (makar mu preostao još samo jedan dan), te bi trebao nakon ramazana ponovo postiti uzastopno dva mjeseca, pošto je prvi pokušaj pravno ništav, tj. nije upotpunjen $s$ dva uzastopna mjeseca. Pravno rješenje, tj. hile u ovome slučaju je da eskivira obavezu ramazana, kako bi ispostio kaznu kefareta. To može samo u situaciji da ode na put i statusom putnika, koji ne mora postiti ramazan, ali mora napostiti propuštene dane - ispostiti preostalu obavezu kefareta.

Slično je i sa zakletvom da se neće oženiti u tom i tom gradu. Da ne bi prekršio zakletvu i bio obavezan ispuniti kaznu kefareta (obavezni otkup), pravno rješenje je izlazak i vjenčavanje izvan, u zakletvi, spomenutog grada.

Kod uvakufljenja i dobrovoljnih davanja bolesnika, u slučaju njegove smrtne bolesti kada nasljednici imaju pravo to osporiti, hile je da dadne izjavu, kako je to ustvari bio vakuf nekog čovjeka (a ne njegovo vlasništvo), pa ga postavio mutevelijom (onaj koji se brine o vakufu) dotičnog vakufa. Tada nasljednici nemaju pravo da ospore ovaj vakuf.

Kod prava šuf'a (pravo preče kupnje za komšiju), pravno rješenje i trik izbjegavanja toga prava, jeste da vlasnik pokloni svoje pravo kupcu, a on njemu pokloni novčanu protuvrijednost. Ili da vlasnik pokloni kupcu dio koji je predmet prava preče kupnje, a proda mu ostatak, i sl.

Pravnici su, na principu preventivne sankcije, zabranili hijel koji nekim dozvoljenim činom žele staviti van snage određeno pravno rješenje i pretvoriti ga u drugu pravnu odredbu. ${ }^{12}$

Obrazloženje za ovo je u mnogobrojnim fikhskim pravilima, koja govore o namjerama i intencijama Šerijata, jer kad Zakonodavac propiše neku pravnu odredbu, utemeljenu na javnoj koristi, zatim

12 Ibid., 4/201. 
dozvoli da se pravnim lukavštinama, doskočicama i fiktivnim rješenjima taj propis stavi van snage, značilo bi kontradiktornost što nije u prirodi šerijatskog pravnog poretka.

Ebu-Hanife je bio nenadmašan pravnik i vrstan poznavalac šerijatskih hili i rješenja za problematične situacije. Znao je solomonski, praktično riješiti nerješive pravne probleme. IbnulKajjim el-Dževzijje, poznati pravni klasičar, spominje neka njegova rješenja pod nazivom min letaif hijel Ebi Hanife (pravne lukavštine Ebu Hanife $)^{13}$ :

1. Došao je neki čovjek, kasno noću, Ebu-Hanifi izloživši mu svoj problem. Njegova žena te noći prestala je razgovarati s njim, što je bio razlog da se zakune kako će je pustiti definitivnim, trostrukim raskidom braka ako do sabaha ne progovori s njim. Pošto je to bio tzv. razvod sa uvjetom, čijim ispunjenjem (a ispunjava se sa ezanom za sabah, ako žena ne progovori) nastupa šerijatski, definitivni razvod braka u kojem se žena više ne može vratiti dotičnom mužu, osim da se uda za drugoga čovjeka, da sa njim živi u bračnoj zajednici koja podrazumijeva bračne (seksualne) odnose, pa ako se poslije razvede, tek onda pravno postoji osnova ponovne šerijatske udaje za prvoga muža. Muž je, znajući to, pokušavao udobrovoljiti ženu da progovori, kako ne bi došlo do definitivnog razvoda. Međutim, ona ga je jednostavno ignorirala. Hile Ebu-Hanife, koju je predložio kao rješenje, sastojala se iz toga da muž ode kod muezzina koji oglašava sabahski ezan i nagovori ga da te noći prouči sabahski ezan prije vremena. U isto vrijeme, muž će i dalje nagovarati ženu da progovori prije sabaha. Tako je i učinio. Žena, naravno, nije htjela progovoriti sve dok nije začula ezan. Onda je tek, pobjednički, progovorila ne znajući da vrijeme sabaha, ipak, još nije nastupilo. Progovaranjem prije nastupa sabahskog vremena, ona je anulirala muževu zakletvu koja je uvjetovala disoluciju braka. Tako je brak, formalno-pravno spašen;

2. Neki je siromašni mladić došao kod Ebu-Hanife žaleći se na visoki mehr (vjenčani dar) koji traži porodica njegove izabranice, sprečavajući mu na taj način ženidbu. Ebu-Hanife ga posavjetova da pozajmi novac i isplati mehr, a nakon ženidbe razglasi kako mora

${ }^{13}$ Ibnul-Kajjim el-Dževzijje, I'alamul-muvekki'in an rabbil-alemin, Darul-kutubili'lmijje, 1991., Bejrut, 4/13. 
bježati sa ženom iz tog mjesta, izbjegavajući vjerovnika kojemu ne može vratiti pozajmljeni novac utrošen za plaćanje mehra. Tako je i učinio.

Porodica žene, do koje su doprle vijesti, poboja se kako će njihova kćerka živjeti daleko od njih, u siromaštvu i bijedi sa siromašnim prezaduženim mužem, pa i oni dođu pitati Ebu-Hanifu za pravni savjet i način kako da spriječe selidbu svoje kćerke. EbuHanife pravno obrazloži kako muž ima pravo selidbe, a žena je obavezna da ga sluša i slijedi. Porodica, radi rješenja situacije, pristade da vrati novac od mehra, kako bi zet mogao vratiti dug i kako ne bi bilo razloga za selidbu. Vidjevši spremnost roditelja da se materijalno žrtvuju za njegovu ženu, muž to htjede da iskoristi, pa uslovi ostanak sa zahtjevom da mu daju više novca, nego što je on dao za mehr.

Međutim, Ebu-Hanife je i za njega imao pravnu doskočicu. Naime, priprijetio je da će proglasiti ženu dužnicom koja zbog duga ima zabranu putovanja iz toga mjesta dok ne vrati dug. Tako se i zet pomiri sa predloženim, a problematičnu situaciju riješiše na zadovoljstvo obaju stranka - hilom, tj. pravnom lukavštinom; ${ }^{14}$

3. Također, prenosi se da se neki čovjek zakleo, kako će spolno općiti sa svojom ženom uz ramazan, što povlači kaznu otkupa za mrsenje ako to uradi, ili za prekršaj zakletve ako to ne uradi. U oba je slučaja dužan kefaret. U toj, naizgled bezizlaznoj situaciji, izbjegavanja kefareta, oko pitanja sankcije za prekršaj mrsenja ili prekršaj zakletve, Ebu-Hanife mu daje rješenje u vidu fetve (pravni savjet, decizija), kojom će izbjeći sankciju za oba prijestupa istovremeno. Pravni savjet ovoga genijalnoga pravnika bio je, da prijestupnik otputuje sa ženom $u$ toku ramazana $i$ čin na koji se obavezao zakletvom, uradi u statusu putnika što je dozvoljeno i ne povlači nikakvu sankciju.

\section{O zabranjenim varkama}

Hile mogu biti haram (zabranjen), o čemu je posebno pisao Ibnul-Kajjim el-Dževzije, posvećujući gotovo čitav tom svoje knjige

${ }^{14}$ Ibid. 
raznim primjerima pravnih lukavština koje nisu dozvoljene. ${ }^{15}$ On je na desetine naslova naslovio sa riječima Ibtal hileti keza... (ništavost hile u tom i tom pitanju...) u kojima je, sa stanovišta Šrijata, veoma argumentovano dokazao ništavost (batil) mnogih pravnih rješenja utemeljenih na hili.

Također, postoji konsenzus ashaba da su hile zabranjene. ${ }^{16} \mathrm{Njih}$ je u tome slijedila i generacija iza njih (generacija tabi'ina). ${ }^{17}$ Imami hadisa smatrali su sve hile zabranjene, kao i pravnici, koji opravdavaju hile, ne dozvoljavaju svaku njenu vrstu.

Ako bi hila bila sredstvo koje dovodi do harama, onda je haram; a ako bi dovodila do pokuđenosti (mekruh), onda je pokuđena. U slučajevima u kojima se ulema razilazi, pravna kvalifikacija hile je predmet razmimoilaženja.

Tako bi hila bila haram u slučaju da žena, koja nema pravnog razloga za razvod, konvertira iz islama da se može razvesti, pa se potom opet vrati u islam. Ili da se da sinu muža od druge žene da bi tim činom došlo do razvoda i sl. Ili da se onaj ko hoće seksualno općiti sa ženom u danu ramazana, što se sankcionira kaznom kefareta retributivnoga karaktera, prije toga čina omrsi jedenjem ili pijenjem, što se mora samo napostiti bez kazne kefareta i sl. ili da imućan čovjek, koji ima obavezu zekjata, svoj imetak pokloni ženi, djetetu ili nekom drugom u koga ima povjerenje, na sat vremena, kako bi se samo prekinuo i izbjegao tzv. havl (period obaveznog posjedovanja imetka za obavezu zekjata) a potom ga ponovo vrati nakon što ta obaveza pravno spadne sa njega, itd. Ova vrsta hili je zabranjena po konsenzusu, a imam Ahmed i drugi smatraju čak i davaoca fetve ovakvoga karaktera nevjernikom, jer time čini prijestup apostazije. Radi ovoga su mnogobrojni učenjaci zabranili Kitabul-hijel (knjigu ili poglavlje o hilama). Ovakve vrste hila se ne vezuju za imame mezheba, iako bi se neke mogle bukvalno primijeniti na usulsku metodologiju koju su oni postavili.

\footnotetext{
${ }^{15}$ Ibnul-Kajjim el-Dževzijje, I'alamul-muvekki'in an rabbil-alemin, Darul-kutubili'lmijje, 1991, Bejrut, Treći tom.

${ }^{16}$ Ibid., 3/136.

${ }^{17}$ Ibid., 3/137.
} 
U Šerijatu se djela tretiraju prema nijjetima (namjere, motivi, pobude). Nijjet, tj. namjera iz koje je učinjeno neko djelo, određuje pravnu prirodu djela; ako je nijjet ispravan, onda je i djelo validno i obrnuto; ako je nijjet neispravan, onda je i djelo ništavo. To se razumije iz vjerodostojne hadiske norme: Djela se prosuđuju po namjerama. Svako će imati samo ono što nanijjeti. ${ }^{18}$

Dakle, svakome pravnom poslu prethodi nijjet po kojem se kvalifikuju djela pravnih subjekata. Ako je pravni subjekt, npr., imao namjeru da hilom, odnosno kupoprodajnim ugovorom koji je u osnovi dozvoljen, dođe do nedozvoljene kamate, onda fiktivni čin trgovine neće promijeniti prirodu toga zabranjenoga djela. Isto će se tako pravno tretirati nedozvoljenim svako djelo i pravni posao u kojem se hilom pokuša izigrati zabrana Zakonodavca. Pravnici su na principu preventivne sankcije zabranili hijel koji nekim dozvoljenim činom žele staviti van snage određeno pravno rješenje i pretvoriti ga u drugu pravnu odredbu. ${ }^{19}$

To bi bilo dozvoljeno samo u slučaju da se dođe do nekoga prava, otkloni neka šteta, ili da se nekome olakša u potrebi i nuždi; s tim da to ne uništava neku korist, niti atakuje na nečije pravo, nego da se samo primijeni pravna lukavština i doskočica kojom bi se trebalo izaći iz neke teške situacije, a ne da bi se na taj način imalo za cilj stavljanje van snage neko pravno rješenje.

\section{Pravni status hile}

Zabranjene pravne lukavštine su one koje ruše temelje vjere ili su u suprotnosti sa šerijatskim intencijama. Ako pretpostavimo da hila ne ruši temelje vjere, niti da je u suprotnosti sa šerijatskim ciljevima i intencijama, uzima se u obzir i kao takva ne potpada pod zabranu niti je nezakonita.

Dakle može da bude jedna od tri vrste:

1. Konsenzusom nezakonita - kao što su hile munafika i licemjera;

\footnotetext{
${ }^{18}$ Hadis bilježe Buharija, Muslim, Ebu-Davud, Tirmizija i Nesaija.

${ }^{19}$ Ibid., 4/201.
} 
2. Konsenzusom dozvoljena - kao što je izgovor riječi apostazije u prisili sa srčanom pomirenošću imanom i kao što je u, prvom slučaju, pokuđenost ili zabranjenost radi prijetvornosti i licemjerstva $u$ negativnom kontekstu, to je upravo suprotno $\mathrm{u}$ ovome drugom primjeru. Apostazija, u drugom slučaju, jeste dozvoljena radi dunjalučke koristi i nepostojanja štete u vremenskom totalitetu, ni ovosvjetske niti onosvjetske - za razliku od prvoga slučaja gdje, po konsenzusu, licemjeru i munafiku nije dozvoljena radi onosvjetske štete. Onosvjetske koristi ili štete preferiraju se, po konsezusu, nad ovodunjalučkim tako, da nije dozvoljeno ovosvjetskom koristi izgubiti onosvjetsku. Općepoznato je u Šerijatu da ono što vodi ka upropaštavanju onosvjetske koristi, nije u skladu sa njegovim ciljevima i intencijama, pa je nezakonito. U ovome smislu je došlo, ono što je došlo od tekstova oko pitanja pokuđenosti i zabrane licemjerstva i munafikluka i svega drugoga, što je na njegovom stepenu. Obje ove kategorije su definitivne;

3. Treća kategorija hile je problematična, nejasna i predmet razmimoilaženja, te pravničkih apstrahovanja iz razloga, jer ne postoji definitivan kategoričan dokaz da se uvrste u prvu ili drugu kategoriju, radi toga što nije jasan ni cilj i intencije Zakonodavca koje treba ostvariti, niti se vidi da je suprotan šerijatskoj koristi u pravnoj stvari koja je propisana. Zato se u ovoj kategoriji hile ulema razilazi, pa ako vide da je hila u skladu sa korišću dozvoljena je, no ako je u suprotnosti onda je zabranjena. ${ }^{20}$

Pravnici koji dozvoljavaju neke vrste hile opravdavaju to sljedećim dokazima iz Kur'ana, sunneta, riječi i postupaka ashaba i imama islamskog ummeta:

1. Ejjub, a. s., se zakleo da će izbičevati ženu. Bičevanje je poznato i uobičajeno na način da se krivac udara bičem određenim brojem udaraca. Međutim, Allah, dž. š., poučava Ejjuba, a. s, kako će se riješiti zakletve, a neće izbičevati ženu: I uzmi rukom svojom snop $i$ njime udari, samo zakletvu ne prekrši $!^{21}$

${ }^{20}$ Ebu-Ishak Ibrahim b. Musa eš-Šatibi, El-Muvafekatu fi usuliš-šeri’ah (Sklad u temeljima islamskog prava), Darul-ma’rife, Bez godine izdanja, 1/663.

${ }^{21}$ Kur'an, Sad: 44.

U komentaru ovog ajeta spominje se Allahov, dž. Š., poslanik Ejjub, a. S., koji se zakleo da će izbičevati svoju ženu sa stotinu udaraca zbog njene greške. Međutim, 
2. U Kur'anu se spominje kako je Jusuf, a. s., podmetnuo pehar svome bratu, kako bi ga varkom zadržao kod sebe - kao vid kazne za kradljivca:

I on poče s vrećama njihovim, prije vreća brata svoga, a onda izvadi čašu iz vreće brata svoga. Mi poučismo Jusufa da tako varku izvede. On po vladarevu zakonu nije mogao da uzme kao roba brata svoga, ali je mogao Allahovim dopuštenjem. ${ }^{22}$

Dakle, u ajetu se eksplicitno spominje, da ga je varci poučio Allah, dž. š., što znači da je to dozvoljeno;

3. U Kur'anu se decidno kaže: Oni su spletke smišljali, ali $i$ mi smo, tako da nisu ni osjetili. ${ }^{23}$ Dakle, Allah, dž. š., obavještava da i On priprema spletke onima koji to smišljaju Njegovim poslanicima (...) A hila nije ništa drugo nego spletka (lukavština) kojom se ostvaruje pravo uzurpirano od zulumćara i grješnika;

4. U Kur'anu se kaže: Licemjeri, doista, pokušavaju Allaha prevariti. Allah je njih prevario... ${ }^{24}$

5. Poslanik, a. s., je putujući u društvu ashaba susreo grupu idolopoklonika, neprijatelja koji su pitali za njihov identitet: Odakle ste? Poslanik, a. s., odgovori: Mi smo od vode. On je ciljao na to da su stvoreni od vode, kako to i Kur'an kaže: Stvorili smo sve živo od vode. ${ }^{25}$ Međutim, idolopoklonici su to protumačili na svoj način, što je i bio cilj Poslanika, a. s., da postigne ovim dvosmislenim odgovorom, tako da su ih, zavedeni ovom hilom, idolopoklonici pustili na miru

\footnotetext{
Allah, dž. Š., ga iskuša bolešću i siromaštvom u kojima mu ostade samo žena, brinući se za njega, radeći i hraneći ga 18 godina. Nakon toliko vremena Ejjub, a. S., se konačno obrati svom Gospodaru dovom (molbom) za pomoć koju mu On usliša, te ozdravi. Zbog iskazanog dobročinstva, lijepoga odnosa, brige i truda koje je njegova žena uložila njegujući ga u situaciji kada su ga svi napustili, Ejjub, a. s., koji se bio zakleo, pokaja se i zaželi prekršaj zakletve. Allah, dž.š, daje mu izlaz u fetvi (pravni savjet, decizija) koja mu omogućava da uzme snop od stotinu palminih grančica s kojima će ženu udariti jedanput izvršavajući tako zakletvu bez pravog, bolnog bičevanja.

Muhammed Nesib er-Rifa'i, Tejsirul-a'lijjil-kadir lihtisari tefsir Ibni Kesir (Olakšavanje Uzvišenog, Moćnog u sažetku tefsira Ibni-Kesira), Bejrut, 1978., 4/35.

${ }^{22}$ Ibid., 12, 76.

${ }^{23}$ Ibid., 27, 50 .

${ }^{24}$ Ibid., 4, 142.

25 Ibid., 21, 30 .
} 
smatrajući ih strancima iz nekog jemenskog plemena, sa obale mora na jugu Arabijskog poluotoka;

6. Sufjan es-Sevri prisustvovao je nekom sijelu. Kada ga je htio napustiti, zabranili su mu, pa im se zakleo da će se vratiti ako ga puste. Potom je izašao i zaputio se bosonog svojim pravcem. Onda se vratio, obuo zaboravljenu obuću i definitivno otišao;

7. Prenosi se vjerodostojno predanje od Humejda b. AbdurRahmana b. A'vfa, preko njegove majke Umm Kulsum, jedne od prvih muhadžirki u islamu, kako je Poslanik, a. s., rekao: Dozvoljeno je slagati u tri slučaja - čovjeku koji nastoji popraviti poremećene odnose između dvojice ljudi koji su se posvađali, slagati ženi i slagati u ratu.

Muhammed b. el-Hasen prenosi od Amra b. Dinara a on od Ša'bija: Ne smeta upotreba hile koja je dozvoljena, jer se njome čovjek služi da bi se riješio harama (nedozvoljenog) i došao do halala (dozvoljenog). Dakle, hila ove i sličnih vrsta je dozvoljena. Ono što ne bi bilo dozvoljeno jeste da čovjek hilom, tj. prevarom, trikom $i$ lukavštinom, bespravno uzurpira pravo drugoga koje mu ne pripada, ili da pravno ništavo (batil) djelo, hilom fiktivno, predstavi kao pravovaljano.

Oni koji zabranjuju hilu misle na onu koja se upotrjebi za dozvolu zabranjenoga i ostavljanje propisanoga. Šerijatski pravnici terminologiju hile, običajno upotrebljavaju za ono što nije dozvoljeno. U zabranjene hile spada kategorija koja može biti vid apostazije, velikoga ili maloga grijeha, a u nezabranjene spadaju pokuđene, dozvoljene, mustehabb (lijepe, poželjne) i vadžib (obavezne) hile.

Tako je hila žene da bi dobila razvod braka, konvertiranjem iz islama, vid apostazije.

Hila žene kako bi razvrgla brak podajući se sinu muža od druge žene, automatski mu postaje zabranjena, pa je i to pravni prijestup (haram).

Zabranjena hila može imati više kategorija:

1. Da bude u osnovi haram (zabranjena) i da joj je cilj haram;

2. Da bude u osnovi dozvoljena, a njena namjera haram; 
3. Da bude sredstvo koje se može iskoristiti kao put i stepenica koja vodi u haram;

4. Da se hilom hoće ostvariti legitimno pravo, ili otkloniti ništavost nekog djela. Ova vrsta se dijeli na sljedeće varijante:

1. Hila koja je u osnovi haram, ali sa ispravnim ciljem i namjerom, kao što je slučaj sa čovjekom koji ima neko legitimno pravo uzurpirano od drugoga koji to niječe, a on nema dokaza da to dokaže. Hila je i da se vlasnik prava posluži podmićenim svjedocima koji će lažno posvjedočiti u njegovu korist, iako o tome ništa ne znaju. U ovome slučaju traženje legitimnog prava je dozvoljeno, ali sredstvo kojim se služi je haram (zabranjen);

2. Hila kojom se način izvršenja nekog pravnog posla učini zakonitim, kao i njegov rezultat. Primjer za to je kupoprodaja koja je potpuno legitiman način za sticanje prava vlasništva. Naravno, da je ova vrsta djelatnosti dozvoljena i nije predmet pravnog razlaza.

Od više vrsta hili dvije vrste mogu biti dozvoljene:

1. hila koja će spriječiti nepravdu, spletku i prevaru;

2. hila koja će otkloniti nepravdu, spletku i prevaru nakon što se dese.

Vrsta hile po kojoj se ne može dati konkretno, generalno rješenje, nego svaki pojedini slučaj treba posebno rješavati, jeste postupak vraćanja istom mjerom.

Ulema se oko ovoga pitanja razišla dotle da su neki dozvolili samostalno, nasilno uzimanje svoga prava provaljivanjem vrata, izbijanjem zida, paljenjem krova i sl., dok su drugi to zabranili smatrajući da stizanje do svoga prava treba obavezno da bude na način obavještavanja onoga kod koga se nalazi. Treći su mišljenja da se rješenje razlikuje u zavisnosti od prirode samog prava; ako se radi o pravu žene, sina ili oca na izdržavanje, onda se ono može uzeti bez obavještavanja, a ako se radi o pozajmici, dugu za neku prodanu robu i slično, onda se vlasnik treba obavijestiti.

Ako se, pak, radi o tome da je neko potvoren, slagano je na njega, lažno svjedočeno protiv njega $\mathrm{i}$ slično tome, onda nije dozvoljeno uzvratiti na isti način itd. 
Ako je nekome učinjena šteta u vidu ubijene životinje i sl., nije dozvoljeno uzvratiti istom mjerom kao ni u slučaju, kada bi uzvraćanje na štetu rezultiralo pretjeranom štetom. Npr. kada bi neko zapalio kuću kao revanš što je i on njemu zapalio. Međutim, ako bi uzvratio na isti način, kao u slučaju razbijanja posude da uzvrati istom mjerom, što je predmet idžtihada gdje nema eksplicitne zabrane $u$ vjerskim izvorima, te bi bilo dozvoljeno.

\section{Etnosocijalna i doktrinarna pokuđenost nezakonite hile}

Dakle, hijel ili meharidž poznati su u hanefijskoj pravnoj školi (mezheb) i njenoj primjeni. Pošto su bosanski muslimani sljedbenici hanefijske pravne škole (mezheb), tako je i narodni pripovjedač zabilježio u pjesmi motiv djevojke koju su udali bez njenoga odobrenja, a ona se poslužila pravnom hilom kako bi riješila svoj problem. Poslužila se varkom na taj način, da po savjetu stavlja u pojas živu pticu čije srce kuca, pa je makar iskaz o živom biću pod pojasom istinit ako nije istinito priznanje koje je u pjesmi spomenuto kao spasonosna hila:

Kad je bila s begom u odaji,

Njojzi beže tiho govorio:

„Đel' djevojko, na bijelu ruku!'

Njemu veli Šećerka djevojka:

,Što ću tebi na bijeloj ruci?

Živo mi je čedo pod pojasom,

Živo čedo Kopčić Alibega!'

To je begu vrlo teško bilo,

Kadiji je brzo odletio,

Da kadija otpusti djevojku.

Kadija je umah otpustio,

Pa je vjenča Kopčić Alibegu.

Narodni pjesnik, kao i narodni junaci, sa jednom naglašenom averzijom gledaju na nevalidnu, nečasnu i nelegitimnu upotrebu hile. 
Takva hila se po narodnom običaju ne čini ni smrtnom neprijatelju, bez obzira na situaciju koja to možda opravdava, i svejedno što će se radi toga možda platiti visoka cijena ili žrtva. Nezakonita hila je nečasna i ne dolikuje muslimanu, kod kojega cilj ne opravdava sredstvo. To se razumije iz pjesama Smrt Luke od primorja i Halil dijeli mejdan s banom od Zadarja:

Svaki od njih voli poginuti,

Već li caru hilu učiniti. ${ }^{26}$

Dok eto ti tri mlada Madžara:

'Koje vam je Hrnjičin Halile?

Hod' Halile da mejdan dijeliš,

A sa našim banom gospodarom.'

...Gonjaše se četiri sahata.

Kad je peti sahat okrenuo,

A sve gleda od Orašca Tale,

Halil mu je jako zapjenio

Polu mutne polu su krvave. ${ }^{27}$

Dakle, ovo je situacija u kojoj je neophodna pomoć mejdandžiji. Halilov sekundant Tale traži dozvolu Muje Hrnjice da bi intervenisao i pomogao njegovom bratu Halilu, što bi, naravno, dovelo i do intervencije suprotne strane. Međutim, Mujo ne dozvoljava, iako se radi o pružanju pomoći njegovom rođenom bratu, jer se hila ne smije činiti. Sramota je prekršiti običaj nemiješanja u dvoboj „makar glava bila u pitanju":

Opet viknu od Orašca Tale:

„O Hrnjico, naša poglavico!

Hoću l' bratu pomoći Halilu,

Da prihvatim bana na poljani?"

\footnotetext{
${ }^{26}$ Kosta Hörmann, Narodne pjesme muslimana u Bosni $i$ Hercegovini, (Priredila i predgovor napisala Đenana Buturović), (Svijetlost, Sarajevo, 1990), 1, 176.

2758 Kosta Hörmann, Junačke pjesme, Sarajevo, 1889., str. 167.
} 
„Nemoj, brate, od Orašca Tale,

Sramota je hilu učiniti!"28

U pjesmi „Halil traži Mujova đogata” spominje se da je đogat Muje Hrnjice ukraden i odveden čime su oblomljena krila Krajine. Halil Hrnjica prerušen u Madžara, četiri godine traga za njim po raznim zemljama i gradovima i konačno ga pronalazi kod Senjanin Ivana u Senju. Izmišlja priču predstavljajući se Ivanu kao Mujin sluga zarobljen zajedno sa roditeljima i mlađim bratom Jankom. Mujo ga je bio zadužio da se brine za đogata. Pošto je ukraden, a on se trebao brinuti o njemu, optužen je kao krivac za to pa se morao zaputiti tražeći konja kako bi spasio vlastitu glavu i svoju porodicu. Nije smio pobjeći u Mađarsku, zbog roditelja i brata koji su još uvijek zarobljeni, iz straha da će ih Mujo pogubiti. Tom pričom zavarava Ivana i uspijeva da dođe do đogata pa čak i da ga izvede van podruma i jaše, jer se đogat nije dozvolio jahati nikome od vremena otmice. Đogat je Halila prepoznao kao svoga bivšeg gospodara dozvoljavajući mu, na opće iznenađenje, da ga izvede iz podruma. Halilu se tako ukazala prilika da pobjegne na brzom đogatu bez ikakvih poteškoća, međutim, on ne želi učiniti hilu i prevaru:

Izvuče ga iz topla podruma,

Pa otišće poljem širokijem,

Bože dragi, što mu đogat radi!

A sve đogat poprijeko skače.

Mislio se Hrnjičin Halile:

,Da bih bježo na Malu Kladušu,

Ja bih mogo lako pobjegnuti,

Ivanu ću hilu učiniti.

Ja sam Bogu jemin učinio,

Da mu hile učiniti ne ću.'

Pa povrati konja b'jeloj kuli. ${ }^{29}$

\footnotetext{
${ }^{28}$ Ibid., 168.

${ }^{29}$ Ibid., 248.
} 
U pjesmi Ženidba Ahmed-bega Vezirovića spominje se kako je Tale od Orašca primijetio da će Husi-bajraktaru biti učinjena hila na mejdanu i da će ga neprijatelji pogubiti topovskom vatrom, makar $\mathrm{i}$ pobijedio u samom dvoboju, pa ga nastoji spasiti svojom intervencijom:

O Ilija, crn ti obraz bio!

Sta će tebi dvanaest topova?

...Ti ćeš Husa topim raznijeti.

Huso, brate, istjeraj alata

Na široko polje Zlatarevo

Ja ću tebi tope pričuvati

Da ti vlasi hilu ne učine.

...A kad vidje od Orašca Tale,

Da mu vlasi hilu učiniše. ${ }^{30}$

Nezakonita, nevalidna i nečasna hila se, dakle, u narodnom običaju smatra pokuđenim, nevaljalim, amoralnim, pravno ništavim činom koji musliman ne smije činiti čak ni u nuždi, kako se razumije iz ovih primjera u narodnim pjesmama. Hila se može očekivati samo od nevjernika, u ovom slučaju od vlaha.

U Glasniku Zemaljskog muzeja u Bosni i Hercegovini naveden je jedan nešerijatski običaj u okolini Prozora, utemeljen na zabranjenoj hili koji pravno elaborira kadija Sadik ef. Ugljen, navodeći:

Hajde zagji u naša sela, gje žive sami muslomani, ili u ona, gdje su izmiješani s kršćanima, pa će ti izmegju ostalog i to udariti u oči, da se $u$ većine muslomanskih seljaka žene ne kriju ni od muslomana, niti od žitelja drugih vjera, nego žene njihove hodaju otkrivene kao $i$ one drugih mileta, ma da se to protivi islamu. Kada pomislimo, da se naši seljaci većim dijelom tvrdo drže vjere i njenih propisa, i da su seljaci uopće pobožniji od svoje braće varošana (šeherlija), to će nam

${ }^{30}$ Ibid., 378. 
onaka njihova navika svakako biti za čudo, zašto se seljak musloman (balija) u pogledu krijenja žene strogo ne drži šerijata.

Kadija Sadik će otkriti uzrok ovog neislamskog običaja u jednom starom običaju, koji na prvi pogled izlazi kao neka vrsta tajnog ropstva. Ovo umišljeno ropstvo dovodi muslomanski seljak u šerijat, te misli, da ovako protiv Śerijata i ne griješi, kad mu se žena ne krije.

Radi se, naime, o tome da prilikom šerijatskog vjenčanja, nakon sklapanja punovažnog bračnog ugovora, muž ili njegov zastupnik pokloni nešto novaca mladi ili njenom zastupniku (osim mehra), što je u narodnom običaju trebalo značiti da je ta mlada kupljena kao robinja. Po Šerijatu robinja se ne mora oblačiti i kriti kao slobodna žena, tako da se i ove žene poslije toga oblače kao i robinje.

Sadik ef. navodi da je: teško iznaći odakle i kakim se načinom ovaj običaj uvukao u glavu našeg seljaka, ostavljajući vještijem peru da istražuje njegov izvor.

Međutim, sa izvjesnom se sigurnošću može utvrditi, da je izvor ovom običaju u činjenici kako se na ovim prostorima primjenjivao hanefijski mezheb koji je sadržavao i neka pravna rješenja utemeljena na hilama tj., pravnim lukavštinama. Tako se neki poznavalac šerijatskog prava našao da primijeni hilu, $u$ ovom slučaju kako bi ušerijatio nepokrivanje žene muslimanke primjenjujući propis o pokrivanju robinja, koje se po Šerijatu mogu otkriti i ne moraju pokrivati, nad slobodnim ženama hilom fiktivne običajne prodaje slobodne žene, čime ona običajno postaje robinjom svome mužu što je nespojivo sa Šerijatom koji je dokinuo sve vidove ropstva, osim u slučaju ratnih zarobljenika. Zato slobodna žena, ni de facto ni de jure, ne može fiktivnom prodajom postati robinja, niti se na njoj mogu primjenjivati propisi ropstva.

Ovo je jednostavan pokušaj hile, nadmudrivanja Allaha, dž. š., i izigravanja Njegovih propisa, što se egzemplarno i drakonski kažnjava čak i na ovome svijetu. U Kur'anu se navodi primjer naroda koji se služio trikovima i hilama u pokušaju preinačavanja prirode zabranjenih djela, pa su zbog toga kažnjeni neuobičajenom, strašnom

31 Čudnovati običaj u muslomanskih seljaka oko Prozora, Glasnik zemaljskog muzeja u Bosni i Hercegovini, VI, Sarajevo, 1894., str. 802. 
kaznom pretvaranja u majmune. U širokom dijapazonu sankcija kojima Uzvišeni Allah kažnjava neposlušne robove i narode nalaze se i dunjalučke (ovosvjetske) masovne kazne egzemplarnog karaktera. Kur'an nam daje primjere drevnih naroda i raznovrsnih kazni koje su ih zadesile zbog njihovih grijeha i neposluha. Narod Ada kaznio je i uništio vjetrom ledenim, silovitim (El-Hakkah: 6), narod Semuda glasom strahovitim (El-Hakkah: 5 i Hud: 69), narod Nuha potopom općim (Hud: 43), narod Luta kišom grumenja od pečena blata koje je neprekidno sipalo obilježeno od Gospodara tvoga (Hud: 82), narod Šu'ajba glasom užasnim (Hud: 94) itd. Njegova kazna nije bila nepravedna prema njima, nego u srazmjeru s grijehom koji su neprestano javno činili.

Ovdje ćemo navesti, kroz hermeneutiku Kur'ana i njegovog kazivanja, jednu posebnu specifičnu kaznu koju su doživjeli Jevreji za jedan, također, poseban i jedinstven način griješenja. Naime, oni su radi pokušaja hile, nadmudrivanja Allaha, dž. š., i izigravanja Njegovih propisa, egzemplarno i drakonski kažnjeni jedinstvenom neponovljivom kaznom na ovome svijetu.

U Kur'anu se navodi primjer drevnog židovskog naroda, koji se služio trikovima i hilama, u pokušaju preinačavanja prirode zabranjenih djela čineći ih dozvoljenima pa su zbog toga kažnjeni neuobičajenom, strašnom kaznom pretvaranja u majmune.

Vama je poznato ono što se dogodilo onima od vas koji su se o subotu ogriješili, kao i to da smo im Mi rekli: ,Budite majmuni prezreni!' (El-Bekare: 65)

Iz hermeneutike ovoga ajeta saznajemo da su Židovi odbili dan džume, kao odabrani praznični dan, tražeći umjesto njega da to bude subota. Petak je bio obavezan praznični dan za sve narode prije židovskog kroz historiju, kao i za muslimane poslije njih. Pošto su oni odbili petak, insistirajući da praznik bude subotom, onda ih je Allah, dž. š., iskušao nečim što im je inače dozvoljeno, tj. zabranom lova i jedenja ribe na Dan svetkovanja. Međutim, jata velikih riba (kitovi), Allahovom odredbom, dolazila su do obale samo subotom. Dakle, ribe je bilo u izobilju odabranim neradnim danom, kada je židovima bilo zabranjeno loviti i jesti ribu. Drugim, radnim danima kada su smjeli loviti, ribe nije bilo ni za lijeka. Povlačila se negdje na pučinu tako da je više nisu ni viđali do subote. 
U Kur'anu se kaže: I upitaj ih o gradu koji se nalazio pored mora kad su propise o suboti kršili: kad su im ribe, na oči njihove dolazile, dok su subotu svetkovali, a kad nisu svetkovali one im nisu dolazile. Eto, tako smo ih $u$ iskušenje dovodili zato što su stalno griješili. (El-A'raf: 163)

$\mathrm{Na}$ koncu, nisu izdržali iskušenje, pa su počeli pojedinačno smišljati trikove kako da zadrže i love ribu subotom, a u isto vrijeme izbjegnu skrnavljenje zabrane lova. Praktično je to započelo u naselju Medjena kada je neki čovjek ulovio kita subotom, svezao ga za kolac poboden na obali, a zatim pustio u vodu. U nedjelju ga je izvadio i ispržio. Tom hilom je htio izigrati propis zabrane lova subotom. Tako je učinio i sljedeće subote. Komšiluk je osjetio miris pržene ribe i taj se trik otkrio. Uskoro su i ostali počeli sa istim poslom tajno i to je trajalo dugo vremena. Allah, dž. š., ih nije kažnjavao sve dok nisu počeli javno raditi i javno prodavati ulovljenu ribu na tržnici.

Drugi se poslužio još originalnijim trikom. Iskopao je rupu na obali do koje je prokopao jarak. Za vrijeme plime valovi bi donijeli ribu u tu rupu. Kada bi se voda povukla jarkom, riba bi ostajala zarobljena i ne bi se mogla vratiti na pučinu.

Iz kur'ansko-sunnetskih normi, a i iz iskustva, zna se da Allah, dž. š., ne trpi javno griješenje i pregonjenje u griješenju i zulumu (nasilje). Kada ono postane opće, javno griješenje na ulici, bez stida i bojazni od kazne, i kada se izgubi nada u popravljanje i kajanje, onda Allah, dž.š., intervenira sa dunjalučkom, kolektivnom kaznom koju požuri, spuštajući je na grješni narod u vidu raznih katastrofa, kataklizmi, u vidu ranije nepoznatih bolesti i sl., kako bi se iza toga nastavila i eshatološka kazna.

Kada je kršenje zabrane postalo javno i masovno, njihova ulema ih je počela upozoravati na grijeh, zabranjujući im takve trikove. Židovi su odbili da prestanu sa lovom braneći se kako love i vade ribu iz vode nedjeljom tj., dozvoljenim danom.

Oni koji nisu činili taj grijeh podijelili su se na dvije grupe opominjače i neutralce. Neutralci su govorili kako to Kur'an bilježi:

A kad neki od njih rekoše: ,Zašto opominjete narod koji će Allah uništiti ili ga teškim mukama namučiti?'- oni odgovoriše: ,Da bismo 
se pred Gospodarom vašim opravdali i da bi se oni grijeha klonili.' (El-A'raf: 164)

Nakon toga su se podijelili. Vjernici su se odvojili u jednom dijelu naselja pregradnim zidom i posebnim gradskim vratima ne miješajući se sa onima koji nisu svetkovali subotu. Davud, a. s., ih je prokleo. Kur'an dalje konstatira:

I kad zaboraviše ono čime su bili opominjani, Mi izbavismo one koji su od nevaljalih djela odvraćali, a teškom kaznom kaznismo grješnike, zato što su stalno u grijehu bili. I pošto su oni bahato odbili da se okane onoga što im se zabranjivalo, Mi smo im rekli: ,Postanite majmuni prezreni!'(El-A'raf: 165-166)

Jedno su jutro vjernici izašli van. Međutim, nevjernici nisu otvarali svoja vrata. Popeli su se na zid i ugledali ih pretvorene u majmunski čopor. Otvorili su im vrata i oni su se razišli po zemlji.

U sažetku tefsira (komentara) Ibn-Kesira spominje se, kako su Židovi istinski pretvoreni u majmune i nisu živjeli poslije toga više od tri dana, ne jedući, ne pijući i seksualno se ne približavajući ženama.

U hermeneutici ovoga ajeta spominje se i mišljenje Mudžahida koji smatra da je ajet metafora o pretvaranju Židova u majmune.

Dakle, u ovom kur'anskom primjeru vidimo da se lukavštinom i trikom ne mijenja status i priroda zabranjenog djela, nego naprotiv, $\mathrm{i}$ pokušaj toga kažnjava se najstrožijom kaznom. Naravno, to što su Židovi lovili zabranjenim danom i prolijevali riblju krv, nije bio veći haram od prolijevanja ljudske krvi i krvi poslanika koje su ubijali, te krvi palestinskih civila, djece, žena i staraca.

Ipak, Kur'an obavještava da je Allah, dž. š., požurio sa ovosvjetskom kaznom prvih, pretvarajući ih u majmune, dok je drugima odložio kaznu za budući svijet. Međutim, u tome ima simbolike. Židovi koji su činili taj prijestup bili su sljedbenici Tevrata (Tore) pretvarajući se da slušaju i poštuju njegove norme, iako su u stvari činili prekršaj. Taj pokušaj izigravanja propisa samo je ličio na pokornost i poštivanje normi, a u biti je bio nedozvoljen čin. Zato je i kazna bila primjerena i ekvivalentna tome. Pretvoreni su u majmune koji samo liče na ljude, a u biti nisu kao ljudi. 
Sličan primjer imamo i u predanju Ibn-Abbasa koje bilježi EbuDavud a Hakim i drugi ga smatraju vjerodostojnim. U njemu se kaže:

Allah je prokleo Židove! Bio im je zabranjen loj a oni su ga prodavali $i$ hranili se time. A kada Allah zabrani da se nešto jede, onda zabrani i korištenje njegovom prodajom.

\section{Umjesto zaključka}

Kod utemeljivača hanefijskoga mezheba, te $u$ njegovim fundamentima i izvorima ne postoji teorija ciljeva i intencija (mekasid) ali se može primijetiti u praktičnim pravnim propisima što je prirodno za hanefijsku metodologiju islamske jurisprudencije baš zbog njene specifičnosti. Metodolozi islamske jurisprudencije hanefijskoga mezheba, dakle, nisu sistematizirali teoriju intencija i ciljeva u mezhebu, ali ova škola kroz praktična pravna rješenja na temelju istihsana, pravnih pravila i poglavlja tzv. hijel ili meharidž, primjenjuju metodu ciljeva i intencija na vrlo originalan način.

Hanefijski pravnici u svome fikhu imaju Kitabul-hijel ili poglavlje El-Herebu minel-haram (Bježanje od harama, odnosno Izbavljenje od harama) ili rješenja u vidu pravnih lukavština, doskočica kojima se ne čini šteta, nego daju pravna rješenja što omogućuju izlaz iz neke teške pravne situacije.

Od više vrsta hili dvije mogu biti dozvoljene:

1. Hila koja će spriječiti nepravdu, spletku i prevaru;

2. Hila koja će otkloniti nepravdu, spletku i prevaru, nakon što se dese.

Hile o kojim se ne može dati konačan sud i konkretno, generalno rješenje unaprijed nego svaki pojedini slučaj treba posebno rješavati, jeste postupak vraćanja istom mjerom.

Ebu-Hanife je bio nenadmašan pravnik i vrstan poznavalac šerijatskih hili ili pravnih lukavština i rješenja za problematične situacije. Znao je solomonski, praktično riješiti nerješive pravne probleme. Ibnul-Kajjim el-Dževzijje, poznati pravni klasičar, spominje neka njegova rješenja pod nazivom Min letaif hijel Ebi Hanife (Pravne lukavštine Ebu-Hanife). 
Nezakonita, nevalidna i nečasna hila se, isto i kod šerijatskih pravnika i u narodnom običaju, smatra pokuđenim, nevaljalim, amoralnim, pravno ništavim činom koji musliman ne smije činiti čak ni u nuždi.

Spominje se i jedan nešerijatski običaj u okolini Prozora utemeljen na zabranjenoj hili. Pokušaji hile, nadmudrivanja Allaha, dž.š., i izigravanja Njegovih propisa, može izazvati egzemplarnu i drakonsku kaznu čak i na ovome svijetu. U Kur'anu se navodi primjer naroda koji se služio trikovima i hilama u pokušaju preinačavanja prirode zabranjenih djela, pa su radi toga kažnjeni neuobičajenom, strašnom kaznom - pretvaranjem u majmune.

\section{Literatura:}

1. Ebu-Zehre Muhammed, Usulul-fiqh (Metodologija islamske jurisprudencije), Darul-fikril-Arebi.

2. Ebul-Hasen Sejfuddin, (El-Amidi), El-Ihkjam fi usulil-ahkjam (Savršenstvo u temeljima pravnih propisa), Darul-kitabil-Arebi, 1984.

3. El-A'jni Bedruddin, U'mdetul-kari'i šerh Sahihul-Buhari (Temelj čitaocu, komentar Buharijeve Vjerodostojne zbirke hadisa), Darul-fikr, Bejrut.

4. El-A'lim Jusuf Hamid, El-Mekasidul-a'mme liš-šsri'atil-islamijje, El-ma'hedula'lemi lilfikril-islami, 1981.

5. El-A'skalani Ibn-Hadžer, Fethul-Bari bišerh Sahihul-Buhari (Pomoć Stvoritelja kod komentara Buharijeve Vjerodostojne zbirke hadisa), Darur-rejjan litturas, Kairo, 1987.

6. El-Burno Muhammed Sidki b. Ahmed, El-Vedžizu fi idahi kavai'dil-fikhilkullijjje (Kompendijum pojašnjenja općih fikhskih pravila), Mektebetul-me'arif, Rijad, 1989.

7. El-Dževzijje Ibnul-Kajjim, I'alamul-muvekki'in an rabbil-alemin, Darul-kutubil'ilmijje, Bejrut, 1991.

8. El-Hadimi Nuruddin, El-idžtihadul-mekasidi, hudžijjetuhu (..). davabituhu (...) medžalatuhu, Kitabul-ummeti, Katar, $1419 \mathrm{H}$.

9. El-Hatib Muhammed, Lemehatun fil-mektebeti vel-bahsi vel-mesadiri, (Hitri pogledi na biblioteke, naučno djelo i literarne izvore), Muessesetur-risale, 1993.

10. El-Karadavi Jusuf, Dirasetun fi fikhi mekasidiš-Šeri'a bejnel-mekasid el-kullijje ven-nususil-džuzijje, Daruš-šuruk, 2005.

11. Er-Rejsuni Ahmed, Nazarijetul-mekasid indel-imam Eš-Šatibi, El-ma'hedila'lemi lilfikril-islami, 1992. 
12. Er-Rifa'i Muhammed Nesib, Tejsirul-a'lijjil-kadir lihtisari tefsir Ibni Kesir (Olakšavanje Uzvišenog, Moćnog u sažetku tefsira Ibn-Kesira), Bejrut, 1978.

13. Es-Sujuti Dželaluddin, El-Ešbahu ven-nezairu fi kava'idi ve furu’i fikhiššafi'ijjeti (Sličnosti i uporednosti u metodologiji i pravu šafijske pravne škole), Darul-kutubil-'ilmijje, Bejrut, 1993.

14. Eš-Šatibi Ebu-Ishak Ibrahim b. Musa, El-Muvafekatu fi usuliš-šeri'ah (Sklad u temeljima islamskog prava), Darul-ma'rife, Bez godine izdanja.

15. Eš-Ševkani Muhammed b. Ali, Iršadul-fuhul ila tahkikil-hakki min ilmil-usul (Vodič znamenitima u postizanju istine u metodologiji islamske jurisprudencije), 1994., Darul-kutubil-'ilmijje.

16. Et-Tahir Muhammed, Usulul-fiqh (Metodologija islamske jurisprudencije), Dar Bu Selame, Tunis.

17. Ez-Zerka Mustafa Ahmed, El-Medhalul-fikhil-a'mm (Opći uvod u islamsko pravo), Darul-fikr, 1968.

18. Ez-Zuhajli Vehbe, Usulul-fiqhil-islami (Metodologija islamske jurisprudencije), Darul-fikr, 1986.

19. Glasnik zemaljskog muzeja u Bosni i Hercegovini, VI, Sarajevo, 1894.

20. Hörmann Kosta, Junačke pjesme, Sarajevo, 1889.

21. Hörmann Kosta, Narodne pjesme muslimana u Bosni i Hercegovini, Priredila i predgovor napisala Đenana Buturović, Svijetlost, Sarajevo, 1990.

22. Ibnu-Nudžejm, El-Ešbahu ven-nezairu ala mezhebi Ebi Hanifeten-Nu'man (Sličnosti i uporednosti pravne škole Ebu-Hanife En-Nu'mana), Darul-kutubil'ilmijje, Bejrut, 1993.

23. I'ved Es-Sejjid Salih, Eserul-urfi fit-tešri'il-islamijj (Uticaj urfa na islamsko zakonodavstvo), Darul-kutubil-džami'i, Kairo, 1979.

24. Kal'atdži Muhammed Revas - Hamid Sadik Kanibi, Mu'džemu lugatil-fukahai, a'rebi-inklizi (Arapsko-engleska enciklopedija šerijatsko-pravne terminologije), Darun-nefais, 1985.

25. Korkut Besim, Kur'an s prevodom, Štamparija kralja Fehda, Medina, 1412. H.

26. Mekasiduš-šeri'ati ve kadajal-a'sr (Ciljevi, intencije u Šerijatu i savremena pitanja), „Centar za izučavanje ciljeva i intencija Šerijata".

27. Sabik Sejjid, Fikhus-sunne (Islamsko pravo u sunnetu), Darul-fikr, Bejrut, 1977.

28.Zejdan Abdul-Kerim, El-Vedžizu fi usulil-fiqh (Kompendij metodologije islamske jurisprudenije), Muessesetur-risale, 1987. 
Prof. dr. Muharem Štulanović, P.H.D.

\section{MAQASID (OBJECTIVES AND INTENTIONS) IN HANEFI LAW SCHOOL}

\section{SUMMARY}

All law systems - old and new, Divine and conventional - are in theory based on obtaining benefit and avoiding damage, with differences in determination of benefit and damage and in methods for avoiding damage and obtaining benefit. Divine systems determine these categories, and logics and reason confirm them, unlike conventional - man made systems, which leave it only to reason.

A necessity emerges in modern times for research and application of objectives and intentions in Islamic law, so that religion could be transferred from theory into practice in all areas of human activity.

Interest for objectives and intentions of Islamic law has appeared for two basic reasons:

1. Spreading of the Islamic world;

2. Unbreakable ties between the idea of objectives - intentions (in Islamic law) and contemporary reformist tendencies.

A determined theory of objectives and intentions (maqasid) as independent law issues and solutions does not exist in Hanefi law school and its fundaments, but because of the nature of this law school and specific qualities of its methodology of Islamic jurisprudence in practical law norms, theory of objectives - intentions is practically in use. Methodologists of Islamic jurisprudence of Hanefi law school have not systemised theory of intentions and objectives in their law school, but this law school originally and intelligently applies method of intentions and objectives through:

3. The principle of istishan:

4. Systematisation of law rules;

5. Chapters of hiyal (law trickery) or maharig. 
This work deals exactly with maqasid (intentions - objectives), so called hiyal in Hanefi law school.

Key words: maqasid, objectives - intentions, Hanefi law school, Shariah, Islamic law, methodology of Islamic jurisprudence, law trickery or artifice 
الأستاذ الدكتور محرم شتولانوفيتش

مقاصد الشريعة في المذهب الحنفي

\section{خلاصة البحث}

كل القوانين، القديمة والجديدة، السماوية والوضعية، تقوم نظرياً على جلب المصلحة ودرء المفسدة، مع الفروق في مفهوم المفسدة أو المصلحة أو طرق لدرء المفسدة أو جلب المصلحة. القوانين السماوية تحدد تلك المفاهيم والعقل والمنطق يؤكدان ذلك، بخلاف القوانين الوضعية التي تعوّل على العقل وحده.

الحاجة إلى دراسة مقاصد الشريعة وتطبيقها ملحّة من أجل نقل الدين من الحيز النظري إلى العملي في شتى بحالات النشاط الإنساني. يعود الاهتمام بمقاصد الشريعة إلى سببين: أحدها: توسع العالم الإسلامي

ثانيهما: العلاقات الوثيقة بين فكرة مقاصد الشريعة والنزعة الإصلاحية المعاصرة. لا توجد في أصول المذهب الحنفي نظرية مدروسة للمقاصد بشكل الأحكام والحلول

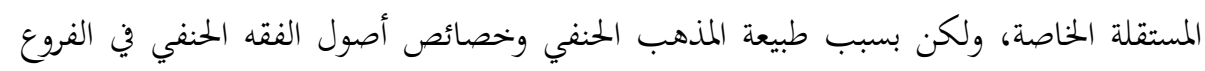
الفقهية فإن نظرية المقاصد مطبقة بشكل عملي. علماء أصول الفقه الأحناف لم يقوموا بتنظيم

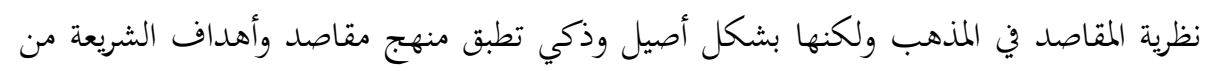
خلال:

$$
\text { مبدأ الاستحسان }
$$

تنظيم القواعد الفقهية

$$
\text { فصول الحيل الشرعية والمخارج }
$$

يتناول هذا البحث بالتحديد مقاصد الشريعة، أو ما يسمى بالحيل الشرعية في المذهب

الكلمات الرئيسة: المقاصد، الأهداف، المذهب الحنفي، الشريعة، الفقه الإسلامي،

$$
\text { أصول الفقه الإسلامي، الحيل الشرعية }
$$

